\title{
Place Strategy in School Marketing: Location, Timing, and Physical Evidence
}

\author{
Hsuan-Fu Ho ${ }^{1}$ \\ ${ }^{1}$ Graduate Institute of Educational Administration and Policy Development, National Chiayi University, Taiwan \\ Correspondence: Hsuan-Fu Ho, Department of Education, National Chiayi University, Taiwan. 85 Wenlong, \\ Minshong, Chiayi County, 62103, Taiwan. Tel: 886-5226-3411-2421. E-mail: hfho@mail.ncyu.edu.tw
}

Received: January 25, 2015 Accepted: February 28, $2015 \quad$ Online Published: May 14, 2015

doi:10.5539/res.v7n7p60 URL: http://dx.doi.org/10.5539/res.v7n7p60

\begin{abstract}
Elementary schools in Taiwan are facing tremendous competition in the market place due to the dramatic decrease of the country's birth rate. As a result, schools are forced to adopt many strategies to survive the competitive market. Place strategy is one of the most important parts of marketing 4Ps, and this research is endeavored to explore what elements of place strategy are most effective in school marketing perceived by parents. Analytic Hierarchy Process was adopted as the major research calculation method, and a self-developed questionnaire was administered to 300 parents in 6 elementary schools. The results indicated that parents mostly considered safe and pleasant neighborhood, followed by well-designed and maintained school construction, up-to-date and decent learning facilities, and quality aesthetic and health facilities. As a result, schools should further stress these elements when promoting their schools.
\end{abstract}

Keywords: marketing 4Ps, place strategy, elementary school, competition

\section{Introduction}

Elementary schools in Taiwan are facing tremendous competition in the marketplace due to the dramatic decrease of the country's birth rate during the past two decades. As of 2009, Taiwan's fertility rate was the lowest in the world, and it was predicted that a lot of schools would close within the next few years if the trend continued. As the birth rate in Taiwan has fallen below one baby per woman in the past few years, the supply of spots in elementary schools dramatically exceeds the demand side, and student enrollment decreases every year. In order to ensure the efficient use of educational resources, the government mandated that schools that failed to recruit enough students will be closed or combined into other schools. Hence, schools are forced to adopt many marketing strategies to survive the fierce competitions in the educational market.

The marketing 4Ps have been widely used by schools to attract more students. The marketing 4Ps are a list of categories of marketing variables summarized into four strategies: product, price, place, and promote.These variables have been widely adopted by business and industrial institutions for marketing strategy development. A considerable body of research on marketing 4Ps exists; however, almost all the research focus has been on the product, price, and promote strategies, and only limited research has investigated the place strategy. Hence, this research endeavors to explore the place strategy in the context of education. The research questions are as follows:

1) What are the dimensions and elements of place strategy in educational marketing?

2) What are the relative weights of aforementioned elements?

3) What is the satisfaction degree perceived by parents toward elements of place strategy?

4) Do parents from different background vary in the perceived importance of elements of place strategy?

\section{Literature Review}

\subsection{School Marketing Mix}

The marketing 4Ps — product, price, place, and promote — introduced in 1960s are a list of marketing variable categories summarized into four strategies. Although many scholars have lamented that the 4Ps cannot cover all of the essential marketing strategies that might be used by industries (Gronroos, 1994), they are widely recognized as the basic model of the marketing mix that might be used to maximize the marketing benefits, and 
industries or companies might expand the marketing 4Ps to a mix of more elements to meet the needs of a particular environment (Zineldin \& Philipson, 2007; Goi, 2009). Previous marketing management studies have tended to focus more on the product and promotion strategies, while ignoring the importance of price and place strategies (Aulakh \& Kotabe, 1992; Chung, 2008).

Kotler and Fox (1985) argued that the place strategy for educational institutions should include four major elements: channels, locations, schedules, and school atmosphere. Lane (1986) referred to place strategy as involving all those aspects of the product distribution process, which includes the channels through which products are delivered, facilities through which the distribution activities are strengthened, the location where the instructions are implemented, and the schedule when school services are offered. Barns (1993) explained that the place strategy for schools refers to efforts related to geographical and physical location, the school environment and atmosphere, and accessibility to and availability of knowledge delivery. Evans (1995) offered a similar explanation of the place strategy for schools, suggesting that the place strategy is related to where and how the course is offered (e.g., quality and ambience of rooms, site, and buildings). He further suggested that place often refers to ensuring that the product is delivered to customers at the right place and the right time; hence, the academic president should focus not only on the school locations and facilities, but also on the school timetable.

\subsection{School Location}

The location of the school is a critical determinant perceived by parents during school selection; indeed, sometimes location and surroundings are more important than school efficiency or student achievement in school promotion (Lubienski, 2007). This is especially true for elementary schools because parents care much about the safety and location proximity.Therefore, it is important for schools to stress the benefits of their location, such as calm surroundings, the beautiful campus, its convenient location, the safe neighborhood, and the supportive community (Johnsson \& Lindgren, 2010).

Evans (1995) further suggested that place strategy is especially essential for schools seeking to attract students from outside their traditional catchment area, because parents might have serious concerns about the additional traveling distance between the home and school. Hence, facilitating access to schools, such as via a well-managed school transportation system, is important for attracting parents with proximity concerns.

\subsection{Physical Evidence}

Children cannot be well educated in an environment that is not conducive to learning; therefore, K-12 parents heavily emphasize the space and school facilities. Quality facilities not only build a good image with parents and the public, but they also increase teacher appreciation and student performance (Lane, Bishop, Gibbs, \& Lane, 2006). School facility and construction design are strongly linked with curriculum delivery, and the school's outdoor learning spaces also enable students to develop their competences in a field setting (Gislason, 2009; Leiringer \& Cardellino, 2011). Moreover, school facilities and building design are important for ensuring that students are in a safe learning environment (McClester, 2011).

A well-designed facility will help schools build their identity, strengthen ties to the community, and engage school stakeholders (Holcomb, 1993; Becker \& Steele, 1995). Visual design is essential as a way to expose an industry's spirit, culture, and promise, which include the shape, color, and function of the buildings and facilities (Steiner, Sundstrom, \& Sammalisto, 2013). Fombrun and van Riel (2004) suggested that five dimensions should be considered for architectural visual design: visibility, distinctiveness, transparency, authenticity, and consistency.

Johnsson and Lindgren (2010) claimed that infrastructure and facilities are school resources and are essential in a school's marketing efforts because parents often make school choice decisions based on abstract images. Well-designed infrastructure and facilities can arouse parents' positive attitudes toward the school. Hence, it is important for schools to stress their quality sports facilities, playground, recreation spaces, libraries, and computer or acoustic centers. Moreover, Frantz (2014) suggested that it is important for schools to involve the media, board members, teachers, community members, and parents in school building and facility development projects so that these physical assets can become symbols of the school, which might win the support of the stakeholders and in turn become advantageous in school marketing campaigns.

\subsection{School Timing}

Evans (1995) stressed that, as the place strategy for schools includes delivering the school products to their customers at the right place and the right time, school administrators should not only focus on elements associated with school location and school facilities, but also ensure that the timetable is adequate for enhancing students' achievements. A school might design its timing by changing the opening time for parents who have to 
rush to their offices and by extending the closing time to allow parents to have sufficient time traveling between their home, workplace, and the school.

Lane (1986) further argued that the program schedule is an important part of the place strategy in the marketing mix. Schools have to decide when to offer courses, including whether the courses should be taken in one semester, two semesters, or three semesters. Sometimes, they have to determine whether there should be some special instructional programs or activities in the summer.

\section{Research Methodology}

\subsection{Analytic Hierarchy Process}

The analytic hierarchy process (AHP) developed by Saaty (1971) is a calculation technique for organizing and analyzing complex decision problems. The major mechanism of AHP is to divide a big problem into several smaller problems and then organize all these problems into a hierarchical structure as Saaty believed that it is easier to solve several smaller problems than solve a big complex problem while problems at the upper level of the structure comprise sub-problems at the lower level. As AHP allows users to assess the relative weight of multiple criteria or multiple options in a clear and easier manner, it has been widely used by decision makers to determine the weights of each decision criterion and to select the best policy options.

The weights or option scores are basically acquired by pair-wise comparison of all factors at the same level in the structure. Research participants are asked to give each pair of criteria a score to indicate which side is more prioritized and the degree of prioritization (a choice from 1 to 9). After completing the parities comparison, positive reciprocal matrixes were adopted to calculate the relative weights of each element.The eigenvalues $\lambda_{\max }$ were then used to check whether an interval comparison matrix is consistent or not, with a CR value smaller than 0.1 indicatingthat the matrix is consistent. We adopted AHP as the major research method because we were endeavoring to compare the relative importance of all the tactics of place strategy in school marketing, and the techniques of pairwise comparisons will create the most precise ratio for variables that are not numerical (Saaty, 1980).

\subsection{AHP Structure}

The first step of AHP is to determine the most important elements or criteria that should be included in the comparison and then organize all the selected elements in a structure for calculation. We thus created a three-layer structure: The first layer is the main goal of finding the most essential elements for place strategy in school marketing. The second layer comprised three dimensions: location, physical evidence, and school timing.Finally, each dimension was composed of three elements (as shown in Figure 1).

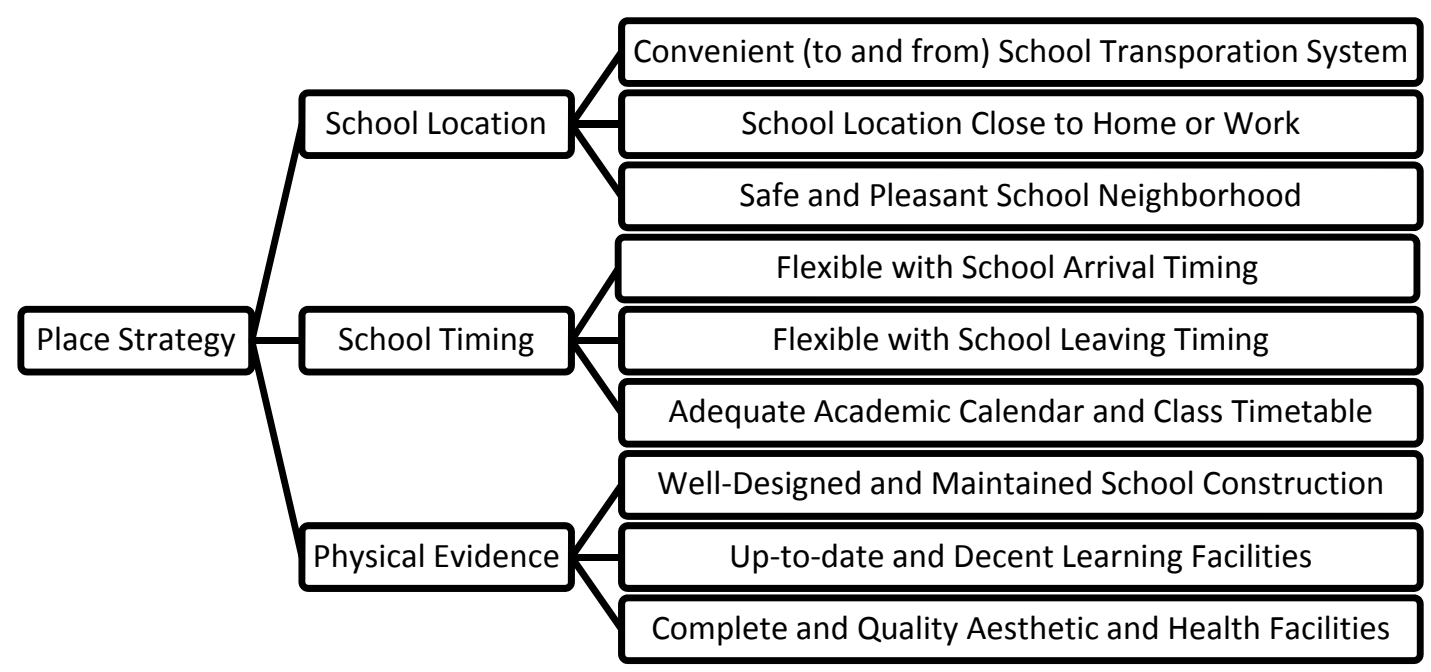

Figure 1. Research Instrument

A self-developed questionnaire entitled "Research Questionnaire of Relative Importance of Place Strategy Perceived by Parents" was adopted as the major research instrument. This questionnaire was composed of three parts. The first part was used to collect participants' demographic data. The second part consisted of 12 AHP questions to acquire the information necessary for calculating the relative weights. Finally, the third part contains 
a 9 questionsusing a 5-point Likert scale to investigate the satisfaction level of the place strategies perceived by parents.

\subsection{Sampling and Participant Components}

The questionnaire was administered to 300 school parents in 6 schools, of which, 229 were received and validated for analysis, resulting in a 76\% response rate. The participants included $96(41.9 \%)$ male parents and $133(58.1 \%)$ female parents; $74(32.3 \%)$ participants came from communities located in the city, $68(29.7 \%)$ came from suburban areas, and $87(38 \%)$ came from rural areas.

\section{Research Results}

\subsection{Relative Weights of Place Strategy Elements}

We first calculated the relative importance of each place strategy element. As shown in Table 1, the results indicated that the physical evidence dimension is more important than the school location and school timingdimensions in terms of school marketing. Moreover, the most important place strategy element perceived by parents when selecting a school is safe and pleasant school neighborhood, followed by up-to-date and decent learning facilities and well-designed and maintained school construction. On the other hand, parents did not show much interest in knowing about flexible school arrival time, flexible school leaving time, and convenient (to and from) school transportation system.

Table 1. Relative weights of elements in place strategy

\begin{tabular}{|c|c|c|c|c|c|c|c|c|}
\hline \multirow[b]{2}{*}{$\begin{array}{l}\text { Main } \\
\text { Goal }\end{array}$} & \multirow[b]{2}{*}{$\mathrm{CR}$} & \multirow[b]{2}{*}{ Dimension } & \multicolumn{2}{|c|}{ Weight } & \multirow{2}{*}{\multicolumn{2}{|c|}{ Strategies }} & \multirow[b]{2}{*}{$\begin{array}{l}\text { Weight to } \\
\text { Dimension }\end{array}$} & \multirow[b]{2}{*}{$\begin{array}{l}\text { Weight } \\
\text { to Main } \\
\text { Goal }\end{array}$} \\
\hline & & & $\begin{array}{l}\text { To } \\
\text { Main } \\
\text { Goal }\end{array}$ & $\mathrm{CR}$ & & & & \\
\hline \multirow{13}{*}{$\begin{array}{l}\text { Finding } \\
\text { Best } \\
\text { Place } \\
\text { Strategy }\end{array}$} & \multirow{13}{*}{.030} & \multirow{5}{*}{$\begin{array}{l}\text { School } \\
\text { Location }\end{array}$} & \multirow{5}{*}{.349} & \multirow{5}{*}{.004} & \multirow{4}{*}{\multicolumn{2}{|c|}{$\begin{array}{l}\text { Convenient } \\
\text { Transportation } \\
\text { Close to } \\
\text { Home or Workplace }\end{array}$}} & \multirow{2}{*}{.167} & \multirow{2}{*}{.058} \\
\hline & & & & & & & & \\
\hline & & & & & & & \multirow{2}{*}{.232} & \multirow{2}{*}{.081} \\
\hline & & & & & & & & \\
\hline & & & & & $\begin{array}{l}\text { Safe and } \\
\text { Neighborhoo }\end{array}$ & Pleasant & .602 & .210 \\
\hline & & \multirow{5}{*}{$\begin{array}{l}\text { School } \\
\text { Timing }\end{array}$} & \multirow{5}{*}{.167} & \multirow{5}{*}{.007} & Flexible & & \multirow{2}{*}{.169} & \multirow{3}{*}{.028} \\
\hline & & & & & Arrival Time & & & \\
\hline & & & & & Flexible & & 225 & \\
\hline & & & & & Leaving Time & & & \\
\hline & & & & & $\begin{array}{l}\text { Adequate } \\
\text { Timetable }\end{array}$ & Class & .606 & .101 \\
\hline & & \multirow{3}{*}{$\begin{array}{l}\text { Physical } \\
\text { Evidence }\end{array}$} & \multirow{3}{*}{.484} & \multirow{3}{*}{.007} & $\begin{array}{l}\text { Good } \\
\text { Construction }\end{array}$ & School & .313 & .152 \\
\hline & & & & & $\begin{array}{l}\text { Decent } \\
\text { Facilities }\end{array}$ & Learning & .382 & .185 \\
\hline & & & & & $\begin{array}{l}\text { Quality Aes } \\
\text { Health Facilit }\end{array}$ & etic and & .304 & .147 \\
\hline
\end{tabular}

\subsection{Weighting Differences between Male and Female Parents}

We next tried to compare the differences in perceptions between male and female parents. The results indicated that both male and female parents predominantly stress safe and pleasant neighborhood. However, male parents stress up-to-date and decent learning facilities as well as well-designed and maintained constructions more than female parents, whereas female parents put much more importance on adequate school calendar and class schedule as well as convenient (to and from) school transportation system than their male counterparts. 
Table 2. Differences of element weights between male and female parents

\begin{tabular}{lll}
\hline Elements of Place Strategy & Male & Female \\
\hline ConvenientTransportation & .065 & .105 \\
Close to Home or Workplace & .082 & .105 \\
Safe and Pleasant Neighborhood & .214 & .202 \\
FlexibleArrival Time & .035 & .045 \\
FlexibleLeaving Time & .039 & .075 \\
Adequate Calendar and Class Timetable & .099 & .152 \\
Good School Construction & .135 & .063 \\
Decent Learning Facilities & .198 & .112 \\
Quality Aesthetic and Health Facilities & .133 & .141 \\
\hline
\end{tabular}

\subsection{Weighting Differences among Parents from City, Suburban, and Rural Areas}

We further investigated whether parents from different backgrounds varied significantly in their rating of the elements. Table 2 indicates that parents from city schools mostly stressed safe and pleasant neighborhood, followed by well-designed and maintained school construction, up-to-date and decent learning facilities, and quality aesthetic and health facilities. Parents from suburban and rural schools showed very similar results as their city counterparts.

Table 3. Differences of element weights among parents living in different locations

\begin{tabular}{llll}
\hline Elements of Place Strategy & City & Suburban & Rural \\
\hline ConvenientTransportation & .061 & .053 & .059 \\
Close to Home or Workplace & .067 & .084 & .091 \\
Safe and Pleasant Neighborhood & .186 & .214 & .225 \\
FlexibleArrival Time & .033 & .018 & .034 \\
FlexibleLeaving Time & .041 & .031 & .040 \\
Adequate Calendar and Class Timetable & .109 & .098 & .095 \\
Good School Construction & .181 & .150 & .130 \\
Decent Learning Facilities & .178 & .190 & .186 \\
Quality Aesthetic and Health Facilities & .144 & .160 & .139 \\
\hline
\end{tabular}

\subsection{Satisfaction Level Perceived by Parents}

Thereafter, we conducted a survey on parents' satisfaction level toward the place strategy elements actually practiced by schools, and the results indicated that parents in general are satisfied with schools' performance on almost all elements as they ranked all elements higher than 3. Parents showed the highest satisfaction with the element of safe and pleasant neighborhood, followed by adequate calendar and class timetable and well-designed and maintained school construction. They gave a lower score to flexible arrival time. 
Table 4. Satisfaction level of parents toward elements of place strategy

\begin{tabular}{lll}
\hline Elements of Place Strategy & Mean & Std. \\
\hline ConvenientTransportation & 3.712 & .984 \\
Close to Home or Workplace & 3.870 & 1.051 \\
Safe and Pleasant Neighborhood & 4.009 & .922 \\
FlexibleArrival Time & 3.476 & .846 \\
FlexibleLeaving Time & 3.555 & .900 \\
Adequate Calendar and Class Timetable & 3.961 & .834 \\
Good School Construction & 3.904 & .927 \\
Decent Learning Facilities & 3.782 & .915 \\
Quality Aesthetic and Health Facilities & 3.638 & .929 \\
\hline
\end{tabular}

\subsection{Satisfaction Level Differences between Male and Female Parents}

A $t$-test was conducted to examine whether males and females had different satisfactionlevels toward schools' actual performance on place strategy elements. The results indicated that male parents were significantly more satisfied than female parents with up-to-date and decent learning facilities and quality aesthetic and health facilities.

Table 5. Satisfaction differences between male and female parents

\begin{tabular}{|c|c|c|c|c|c|}
\hline Elements of Place Strategy & Gender & Mean & $\mathrm{SD}$ & $\mathrm{T}$ & $\operatorname{sig}$ \\
\hline \multirow{2}{*}{ Convenient Transportation } & Male & 3.813 & .921 & \multirow{2}{*}{1.317} & \multirow{2}{*}{.189} \\
\hline & Female & 3.639 & 1.024 & & \\
\hline \multirow{2}{*}{ Close to Home or Workplace } & Male & 3.844 & .998 & \multirow{2}{*}{-.308} & \multirow{2}{*}{.758} \\
\hline & Female & 3.887 & 1.092 & & \\
\hline \multirow{2}{*}{ Safe and Pleasant Neighborhood } & Male & 3.958 & .961 & \multirow{2}{*}{-.702} & \multirow{2}{*}{.484} \\
\hline & Female & 4.045 & .895 & & \\
\hline \multirow{2}{*}{ Flexible Arrival Time } & Male & 3.604 & .827 & \multirow{2}{*}{1.961} & \multirow{2}{*}{.051} \\
\hline & Female & 3.384 & .850 & & \\
\hline \multirow{2}{*}{ Flexible Leaving Time } & Male & 3.531 & .846 & \multirow{2}{*}{-.333} & \multirow{2}{*}{.740} \\
\hline & Female & 3.571 & .940 & & \\
\hline \multirow{2}{*}{ Adequate Calendar and Class Timetable } & Male & 4.000 & .795 & \multirow{2}{*}{.605} & \multirow{2}{*}{.546} \\
\hline & Female & 3.932 & .863 & & \\
\hline \multirow{2}{*}{ Good School Construction } & Male & 3.896 & .864 & \multirow{2}{*}{-.112} & \multirow{2}{*}{.911} \\
\hline & Female & 3.910 & .973 & & \\
\hline \multirow{2}{*}{ Decent Learning Facilities } & Male & 3.938 & .856 & \multirow{2}{*}{2.207} & \multirow{2}{*}{.028} \\
\hline & Female & 3.669 & .943 & & \\
\hline \multirow{2}{*}{ Quality Aesthetic and Health Facilities } & Male & 3.875 & .784 & \multirow{2}{*}{3.358} & \multirow{2}{*}{.001} \\
\hline & Female & 3.466 & .989 & & \\
\hline
\end{tabular}

\subsection{Satisfaction Differences among Parents from Different School Locations}

Finally, we examined the satisfaction level with the place strategy elements. The results indicated that parents from rural areas were less satisfied with up-to-date and decent learning facilities and flexible school leaving time 
than their city counterparts. Parents from rural areas were also less satisfied with well-designed and maintained school constructions than parents from suburban schools. These results revealed, to a certain degree, an inequity phenomenon in Taiwan's elementary school system.

Table 6. Satisfaction differences among parents from different locations

\begin{tabular}{|c|c|c|c|c|c|c|}
\hline Elements of Place Strategy & Gender & Mean & SD & $\mathrm{F}$ & Sig & Post-hoc \\
\hline \multirow{3}{*}{ Convenient Transportation } & 1. City & 3.838 & .876 & & & \\
\hline & 2. Suburban & 3.588 & 1.136 & 1.149 & .319 & \\
\hline & 3. Rural & 3.701 & .942 & & & \\
\hline \multirow{3}{*}{ Close to Home or Workplace } & 1. City & 4.041 & 1.026 & & & \\
\hline & 2. Suburban & 3.794 & 1.100 & 1.464 & .234 & \\
\hline & 3. Rural & 3.782 & 1.028 & & & \\
\hline \multirow{3}{*}{$\begin{array}{l}\text { Safe and } \\
\text { Neighborhood }\end{array}$} & 1. City & 4.041 & .957 & & & \\
\hline & 2. Suburban & 3.927 & .903 & .383 & .682 & \\
\hline & 3. Rural & 4.046 & .914 & & & \\
\hline \multirow{3}{*}{ Flexible Arrival Time } & 1. City & 3.581 & .860 & & & \\
\hline & 2. Suburban & 3.426 & .834 & .843 & .432 & \\
\hline & 3. Rural & 3.425 & .844 & & & \\
\hline \multirow{3}{*}{ FlexibleLeaving Time } & 1. City & 3.770 & .869 & & & \\
\hline & 2. Suburban & 3.529 & .906 & 3.679 & .027 & $(1)>(3)$ \\
\hline & 3. Rural & 3.391 & .894 & & & \\
\hline \multirow{3}{*}{$\begin{array}{l}\text { Adequate Calendar and Class } \\
\text { Timetable }\end{array}$} & 1. City & 4.068 & .833 & & & \\
\hline & 2. Suburban & 3.927 & .816 & .921 & .400 & \\
\hline & 3. Rural & 3.897 & .850 & & & \\
\hline \multirow{3}{*}{ Good School Construction } & 1. City & 3.987 & .972 & & & \\
\hline & 2. Suburban & 4.132 & .790 & 5.719 & .004 & $(2)>(3)$ \\
\hline & 3. Rural & 3.655 & .938 & & & \\
\hline \multirow{3}{*}{ Decent Learning Facilities } & 1. City & 3.987 & .867 & & & \\
\hline & 2. Suburban & 3.853 & .797 & 4.970 & .008 & $(1)>(3)$ \\
\hline & 3. Rural & 3.552 & .997 & & & \\
\hline \multirow{3}{*}{$\begin{array}{l}\text { Quality Aesthetic and Health } \\
\text { Facilities }\end{array}$} & 1. City & 3.770 & .884 & & & \\
\hline & 2. Suburban & 3.647 & .958 & 1.494 & .227 & \\
\hline & 3. Rural & 3.517 & .938 & & & \\
\hline
\end{tabular}

\section{Conclusions and Implications}

Although place strategy is one of the most important parts of the school marketing mix, it is not often considered by schools when developing marketing strategies due to a lack of guidance in place strategy. This research has thus endeavored to clarify the elements that should be considered by school marketers when developing place strategy and to calculate the relative weights of each element. In addition, this research also sought to examine the perceptions and satisfaction level differences among parents from different backgrounds.

The results showed that parents mostly considered safe and pleasant neighborhood, followed by well-designed and maintained school construction, up-to-date and decent learning facilities, and quality aesthetic and health facilities. As a result, schools should further stress these elements when promoting their schools.

The research results also indicated that male parents emphasize very different elements than female parents do. 
Schools should stress quality construction, facilities, and equipment more when marketing to male parents, but put more emphasis on convenient transportation and well-developed school calendar and class timetable when marketing to female parents.

It is also worth noting the satisfaction differences among parents from different school locations. Parents from rural areas were less satisfied with the flexible school leaving time, well-designed and maintained construction, and up-to-date and decent learning facilities than their city and suburban counterparts. This result might stem from the trend that the government often invests less in rural schools than city schools.Therefore, Taiwan's government should carefully review whether schools in less advantaged areas are enjoying an equal treatment as their city and suburban counterparts if the aim is to accomplish educational equity.

Finally, in the future qualitative approach such as in-depth interviews or focus group interviews could be used to explore the explanations of the differences between male and female parents and the varieties among parents from different locations.

\section{References}

Aulakh, P. S., \& Kotabe, M. (1992). An assessment of theoretical and methodological development in international marketing: 1980-1990. Journal of International Marketing, 1(2), 5-28.

Barns, C. (1993). Practical marketing for schools. Cambridge, MA: Blackwell Publishers.

Becker, F., \& Steele, F. (1995). Workplace by design: Mapping the high performance workspace. San Francisco, CA: Jossey-Bass.

Chun, H. F. L. (2008). The impact of a centralized organizational structure on marketing standardization strategy and performance: The experience of price, place and management processes. Journal of Global Marketing, 21(2), 83-107. http://dx.doi.org/10.1080/08911760802135152

Evans, I. (1995). Marketing for schools. New York, NY: Cassell.

Fombrun, C. J., \& Van Riel, C. B. M. (2004). Fame and fortune: How successful companies build winning reputations. Upper Saddle River, NJ: Prentice-Hall.

Frantz, J. T. (2014). The bricks and mortar superintendency: How to survive a building project. Education, 134(3), 384-394.

Gislason, N. (2009). Mapping school design: A qualitative study of the relations among facilities design, curriculum delivery, and school climate. Reports and Research, 40(4), 17-33. http://dx.doi.org/10.3200/JOEE.40.4.17-34

Goi, C. L. (2009). A review of marketing mix: 4Ps or more? International Journal of Marketing Studies, 1(1), 2-15. http://dx.doi.org/10.5539/ijms.v1n1p2

Gronroos, C. (1994). From marketing mix to relationship marketing: Towards a paradigm shift in marketing. Management Decision, 32(2), 4-20. http://dx.doi.org/10.1108/00251749410054774

Holcomb, J. H. (1993). Educational Marketing: A Business Approach to School-Community Relations. New York, NY: University Press of America.

Johnsson, M., \& Lindgren, J. (2010).“Great location, beautiful surrounding!” making sense of information materials intended as guidance for school choice. Scandinavian Journal of Educational Research, 54(2), 173-187. http://dx.doi.org/10.1080/00313831003637956

Kotler, P., \& Fox, K. F. A. (1985). Strategic marketing for educational institutions. Englewood Cliffs, NJ: Prentice-Hall.

Lane, J. J. (1986). A marketing plan for public school management. In J. J. Lane (Ed), Marketing Techniques for School Districts. Reston, VA: Association of School Business Officials International.

Lane, R. J., Bishop, H. L., Gibbs, J. E., \& Lane, L. J. (2006). Appraisal of K-12 school physical structures: A model for facilities assessment. Education, 126(4), 599-608.

Leiringer, R., \& Cardellino, P. (2011). Schools for the twenty-first century: School design and educational transformation. British Educational Research Journal, 37(6), 915-934. http://dx.doi.org/10.1080/01411926.2010.508512

Lubienski, C. (2007). Marketing schools: Consumer goods and competitive incentives for consumer information. Education and Urban Society, 40(1), 118-141. http://dx.doi.org/10.1177/0013124507303994 
McLester, S. (2011). Designing safe facilities. District Administration, 47(8), 71-78.

Saaty, T. L. (1971). How to make a decision: The Analytical Hierarchy Process. European Journal of Operational Research, 40(1), 9-10.

Saaty, T. L. (1980). The Analytic Hierarchy Process. New York: McGraw Hill.

Steiner, L., Sundstrom, A. C., \& Sammalisto, K. (2013). An analytical model for university identity and reputation strategy work. Higher Education, 65, 401-415. http://dx.doi.org/10.1007/s10734-012-9552-1

Zineldin, M., \& Philipson, S. (2007). Kotler and Borden are not dead: Myth of relationship marketing and truth of the 4Ps. Journal of Consumer Marketing, 24(4), $229-241$. http://dx.doi.org/10.1108/07363760710756011

\section{Copyrights}

Copyright for this article is retained by the author(s), with first publication rights granted to the journal.

This is an open-access article distributed under the terms and conditions of the Creative Commons Attribution license (http://creativecommons.org/licenses/by/3.0/). 